\title{
学業場面における不健全完全主義者の動機づけに 随伴性自己価值および失敗の反すうが及ぼす影響
}

\author{
胡（増井）綾及 \\ 岩永誠 \\ 広島大学大学院総合科学研究科 \\ 広島大学大学院総合科学研究科
}

\begin{abstract}
不健全完全主義者は目標を達成できないにもかかわらず，学業課題へ高い目標を掲げる傾向がある。彼 らの学業への動機づけはなぜ高く維持されるのか。本研究は不健全完全主義者の示す学業への高い動機つ” けの媒介要因を検討することを目的とした。大学生 185 名を対象に完全主義, 随伴性自己価值, 失敗の反す う, 日常の学業課題への動機づけとの関連を検討した。その結果, 完全主義的努力は達成動機に正の直接 効果を示した。活動基盤自己価值は，完全主義的努力と競争的達成動機の間を媒介している傾向が示され た。一方完全主義的眯念は, 自己充実的達成動機には負の直接効果を, 失敗回避動機には正の直接効果を 示した。また失敗の反すうは，完全主義的懸念と失敗回避動機の間を媒介していた。以上のことから，不 健全完全主義者の学業への高い動機づけは, 活動基盤自己価值や失敗の反すうに媒介されて生起している と考えられる。
\end{abstract}

キーワード : 完全主義, 随伴性自己価值, 失敗の反すう, 達成動機, 失敗回避動機

\section{問題と目的}

完璧な結果を目指して努力する姿勢は, 一般に 望ましい。しかし完全な結果を得ることは困難で あり，失敗して挫折感を味わうことにもつながる ことから，不適応に結びつく危険性がある。

自己に完全性を求める特性である完全主義に は，(1)高い達成基準を自己に課す，(2)些細な失敗 にも過敏に反応する，という特徴がある（Frost, Marten, Lahart, \& Rosenblate, 1990)。完全主義者 は，些細な失敗であってもそのせいですべてが台 無しになったと評価するために, 絶望感や無力感 を高めやすい。そのため完全主義はうつ病の発症 リスクの一つとされている（桜井・大谷, 1997）。 また，物事は完全に成し遂げるべきだという完全 主義者の不合理な信念は, 自身の行動への疑念を 引き起こすことになり, 強迫性障害とも結びつく 恐れがある（Frost et al., 1990）。意味がないとわ
かっていても失敗を防ぐために過剩に取り組まざ るを得ない完全主義者の行動（石田，2005）は, 強迫性障害に見られる行動制御の歪みと類似して いる。

Stoeber \& Otto（2006）は，完全主義の達成基 準を “完全主義的努力 (perfectionistic strivings)” 次元, 完全主義の失敗への過敏性を“完全主義的 懸念 (perfectionistic concerns)” 次元と定義し, その 2 次元の組合せで完全主義を分類する完全主 義の二次元モデルを提唱した。完全主義的努力傾 向が高いほど, 高い目標を掲げて課題に取り組む ことから, 完全主義的努力が完全主義の基盤であ ると考えられている。一方完全主義的懸念傾向が 高いと, 犯した失敗を深刻に評価し, 些細な失敗 であっても許容できないため, 完全主義的懸念の 高さが不適応性を規定すると考えられている。こ れらの組合せより完全主義者は，(1)完全主義的懸 念傾向の高さに関係なく完全主義的努力傾向が低 
い“非完全主義者”, (2)完全主義的努力傾向が高 く完全主義的懸念傾向は低い“健全完全主義者”, (3)完全主義的努力傾向と完全主義的懸念傾向が共 に高い“不健全完全主義者”の3群に分類される。 健全完全主義者は多少の失敗なら許容でき, 高い 目標に取り組むことで自己評価や満足感等を高め ることができるため, 完全主義者といっても適応 的である。一方不健全完全主義者は，健全完全主 義者と同様に高い目標を掲げて課題に取り組む が, 完全主義的懸念傾向が高いために失敗を深刻 に捉えてしまい，目標と成果とのずれを感じやす いことから不適応に陥りやすい。

不健全完全主義者は学業課題に対して高い目標 を設定することに加え, 些細な失敗も許容できな い。そのため, 課題を上手く遂行できていないと 感じ, 絶望感や無力感を抱きやすい（桜井·大谷, 1997)。一般に, 絶望感や無力感を抱くと学業課 題への動機づけは低くなるが, 不健全完全主義者 は次の学業課題になると再び高い目標を掲げて課 題に取り組むことが指摘されている（Bieling, Israeli, Smith, \& Antony, 2003)。なぜ不健全完全 主義者は達成動機や失敗回避動機を高く維持し 続けるのだろうか。これまで (e.g., Bieling et al., 2003), 学業場面を用いて不健全完全主義者の動 機づけに関する検討は行われてきたが, この動機 づけの維持を規定している要因に関する検討は十 分に行われているとは言えない。そこで本研究 は, 学業課題への動機づけを特にイメージしやす い大学生を対象とし, 学業場面における不健全完 全主義者の示す高い動機づけの媒介要因を検討す る。

行動強化理論（Skinner, 1938）からすれば, 不 健全完全主義者が学業課題へ高い動機づけを抱き 続けるのは, 完全性を目指すことに何らかの利点 があるためだと推察される。高い達成動機を抱く ようになる機序として社会的期待モデルが, 高い 失敗回避動機を抱くようになる機序として社会的 反応モデルが提唱されている (Flett, Hewitt,
Oliver, \& Macdonald, 2002)。

社会的期待モデルによると, 周囲の他者からの 高い期待に子供が応えたときに与えられる賞賛が 報酬となり, 高い目標を立てる行動が定着すると 考えられている (Flett et al., 2002)。その結果, 自己に高い達成基準を設定するという完全主義的 努力傾向を高めることにつながる。完全主義的努 力傾向が高いほど, 課題に取り組むことで自己を 高く評価すること（活動基盤自己価值：活動価 值）や，優れた成果を得ることで自己を高く評価 すること（成功基盤自己価值：成功価值）といっ たように，特定の事柄に基づいて自己価值を評価 する (随伴性自己価值) 傾向にあることが指摘さ れている (DiBartolo, Frost, Chang, LaSota, \& Grills, 2004）。このことより, 完全主義的努力傾向の高 い者は, 課題への取り組みや高い成果に基づいて 自己を高く評価しようとするため, 日々の学業課 題への達成動機を高く維持していると予想され る。ただし, 完全主義的努力傾向が高い者は, 失 敗すると罰が与えられる場合でも, あえて困難な 課題を選択することが示されている（Kobori, Hayakawa, \& Tanno, 2009)。このことから，優れ た成果を挙げることで賞賛が与えられて自己評価 を高める経験を繰り返すことで, 完全主義的努力 傾向の高い者は, 報酬とは関係なく高い目標を設 定するという行動自体を内在化するようになると 推察される。そこで大学生を対象とする本研究で は, 他者より高い成果を目指す “競争的達成動機 (堀野・森, 1991)”だけではなく, 成果とは関係 なく独自の基準の達成を目指す “自己充実的達成 動機（堀野・森，1991）”に対しても, 随伴性自 己価值に媒介されて完全主義的努力が及ぼす影響 を検討する。

社会的反応モデルによると, 幼少期に課題を上 手にできないことで罰を繰り返し受けたことに苦 痛を感じ, 罰を受けないよう自己防衛をするため に失敗を防ごうとする行動が定着すると考えられ ている（Flett et al., 2002）。その結果, 些細な失 
敗も見落とさないことで失敗や批判を回避しょう とするという完全主義的懸念傾向を高めることに つながる。完全主義的懸念傾向が高い者は犯した 失敗が頭から離れず，失敗は克服すべきだという プレッシャーを自身にかける傾向がある（Frost＆ Henderson, 1991)。そのため失敗しても, 次の課 題になると再び高い失敗回避動機を抱くと考えら れている。このことから, 完全主義的懸念傾向が 高い者はあえて失敗を繰り返し考える“失敗の反 すう”を行うことで失敗への注意を喚起し，失敗 回避動機を高く維持し続けると予想される。一般 に失敗などの不快な事柄を反すうすることはネガ ティブ感情と結びつくため（伊藤・上里，2001）, 学業課題への動機づけは低下すると考えられる。 しかし不健全完全主義者は課題への取り組みや成 果に自己価値を置いている（Shafran, Cooper, \& Fairburn, 2002）ため, 失敗の反すうを行っても 学業課題への動機づけは低下しないと予想され る。

このように, 完全主義的努力傾向が高いほど課 題への取り組みや成果に基づいて自己評価を行う 傾向があるため, 学業課題へ高い達成動機を示す と想定される。自己に課した目標を達成できな かったとしても, 学業課題に取り組んだことや, 次の学業課題で成果を得るために尽力することで 自己を正当化しょうとするため, 達成動機の高さ は維持されると予想される。また, 完全主義的懸 念傾向が高いほど失敗の反すうを行うことで失敗 へ注意を向け続けることから, 次の学業課題の失 敗回避動機の高さにつながると予想される。

本研究の目的は, 不健全完全主義者の学業課題 への高い動機づけの媒介要因として随伴性自己価 值や失敗の反すうを想定し, 完全主義と学業課題 への動機づけとの関連性におけるそれらの媒介効 果を検討することである。これまで社会的期待モ デルおよび社会的反応モデルで主に検討されてき たのは, 完全主義傾向と親の養育態度との関連 （Flett et al., 2002）についてであり，完全主義的
努力や完全主義的懸念が学業課題への動機づけに 及ぼす影響の媒介過程は検討されていない。完全 主義と学業課題への動機づけの間の媒介過程を明 らかにすることで，不健全完全主義者が不適応へ 至るプロセスへの介入に資する情報を得られると 期待される。

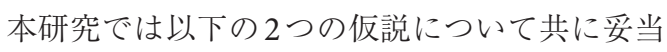
であるかを検討する。仮説 1 ：完全主義的努力は, 随伴性自己価值に媒介されて自己充実的達成動機 や競争的達成動機を高める。仮説 2 : 完全主義的 懸念は, 失敗の反すうに媒介されて失敗回避動機 を高める。

\section{方 法}

調査時期・対象者 2012 年 6 月，心理学の講義 後に集団式調查を行った。回答時間は 15-20分で あった。対象者は大学生246名で, 久損や誤った 回答のあった 61 名を除き1), 185 名（男 72 名, 女 112 名, 不明 1 名, 平均年齢 19.5 歳 $(S D=1.84))$ を分析対象とした。

質問紙の構成 本研究で用いた尺度のオリジナ ル版は 5 件法や 7 件法で評定されている。しかし 調査対象者にとって同じ質問紙において件法が異 なる質問項目が混在すると回答しにくくなる恐れ があるため, 本研究ではすべて0-5の6件法（0： 全く当てはまらない-5：非常に当てはまる）に統 一した。本調査で用いる質問項目について, 本論 文の著者や共著者, 心理学を専攻する大学院生 6 名と大学生 2 名によって, 各尺度の文意がわかり やすいか, 内容的に妥当であるかを確認し, 文意 を変えない程度にわかりやすい表現に変更した。

1）分析対象者から除外した 61 名の内訳は以下の通りで ある。協力の得られなかった者は9名であった。ま た，回答に欠損や重複のあった者は26名であった。 リッカート尺度の数字と数字の間に回答を行った者 や, 20 項目以上の連続した質問項目のすべてに同じ 回答を行った者など, 信頼性が低いと思われる回答 を行った者は 26 名であった。 
完全主義＼cjkstart完全主義の測定には新完全主義尺度 （桜井・大谷，1997）を用いた。新完全主義尺度 は Frost Multidimensional Perfectionism Scale （FMPS; Frost et al., 1990）を和訳した尺度であ り，高目標設置（自分に高い目標を課する傾向） 尺度, 失敗過敏（失敗を過度に気にする傾向）尺 度, 行動疑念（自分の行動に漠然とした疑いをも つ傾向）尺度のほか, 桜井・大谷（1997）が完全 主義の中核として独自に加えた完全性欲求（完全 でありたいという欲求）尺度の 4 つの下位尺度か ら構成されている。FMPSの下位尺度のうち高目 標設置尺度および失敗過敏尺度はそれぞれ完全主 義的努力と完全主義的懸念に分類されている (Stoeber \& Otto, 2006)。そこで, 新完全主義尺 度の高目標設置尺度を用いて完全主義的努力の程 度を, 失敗過敏尺度を用いて完全主義的懸念の程 度を測定することとした。いずれの下位尺度共に 5項目から構成されていた。なお新完全主義尺度 の完全性欲求尺度は, Stoeber \& Otto（2006）の 完全主義の下位尺度の分類には含まれていないた め分析には用いなかった。また, 行動疑念尺度は 完全主義と強迫神経症との類似性から設けられた 下位尺度であり（Frost et al., 1990）, 厳密には完 全主義を測定していると言えないため, 分析には 用いなかった。

随伴性自己価値 随伴性自己価值は, Contingent Self-Worth Scale (CSWS; DiBartolo et al., 2004) を和訳して用いた。原著者から尺度の翻訳と使用 の許諾を得て、第一著者が翻訳を行った。訳した 項目は日本語, 英語ともに精通した在日アメリカ 人心理学者に依頼し, バックトランスレーション を行い, 適切な日本語であることを確認した。下 位尺度である活動価值尺度と成功価值尺度を用い た。なお，成功価值尺度の「自分が何か失敗して しまったら，挫折してしまう」という項目につい ては, 大学生が日常の学業課題で挫折を経験する ことは極めて稀であり, 調査対象者が想像しにく いと考えられることから，「自分が何か失敗して
しまったら，打ちひしがれてしまう」に変更した。 活動価值尺度では「自分自身のことを正しいと感 じるためには，常に目標や成果に向けて努力しな ければならないと思う」等の 4 項目を, 成功価值 尺度では「自分の価值が, 成し遂げたことによっ て決まるとは思わない(逆転項目)」等の3 項目 を用いた。

失敗の反すう 失敗の反すうは，ネガティブな 反すう尺度（伊藤 ·上里, 2001）と没入尺度 (坂 本，1997）の反すうや没入する内容を「失敗」に 変更して使用した。例えば「過ぎ去ったことにつ いて，あれこれ考えることが多い」は「過ぎ去っ た失敗について，あれこれ考えることが多い」と 変更した。質問内容を「失敗」に限定しても違和 感のない文章となること, 大学生に回答しやすい ことを考慮した結果, 「長い間, 自分が失敗した ことについて思いをめぐらせていることがよくあ る」「失敗したことについて考え始めたら，なか なかそれを止めることができない」,「同じ失敗を 何度も繰り返して考える傾向がある」に上記の例 を加えた 4 項目を用いた。

動機づけ 本研究では講義やゼミ, レポート, 宿題等の大学における日常の学業課題場面を想像 させ, 以下の動機づけを測定した。（a）達成動 機：達成動機測定尺度（堀野·森, 1991）の下位 尺度である自己充実的達成動機尺度と競争的達成 動機尺度から各4項目を選択して用いた。大学生 が日常の学業課題に抱く動機づけであることや, 元の尺度の項目の因子負荷量の高さを考慮して質 問項目を選択した。なお, 自己充実的達成動機尺 度の「結果は気にしないで何かを一生懸命やって みたい」という項目は取り組む対象が曖昧に表現 されているため,「結果は気にしないで課題を一 生懸命やってみたい」に表現を変更した。自己充 実的達成動機尺度では「いろいろなことを学んで 自分を深めたい」動機を, 競争的達成動機尺度で は「他人と競争して勝つとうれしい」動機を測定 している。（b）失敗回避動機：失敗回避動機は, 
失敗回避動機尺度（西田，2009）を参考に4 項目 を作成した。元の尺度では1-7の7件法で測定さ れていたが，本研究では0-5の6件法で測定した。 「ちょっとした失敗も見逃したくない」，「失敗を 避けるためなら何でもする」という項目を用い た。

研究倫理 本調查結果は広島大学大学院総合科 学研究科倫理委員会の承認を得て公表された（受 付番号 26-13)。調査対象者に対し, 回答時に, 回答は任意であることや回答を中断しても不利益 を被らないこと, 統計的に分析するため個人が特 定されることはないことを教示し, 調査協力への 同意を求めた。

\section{結 果}

分析 新完全主義尺度については，2因子を想 定した最尤推定法による確認的因子分析を行っ た。なお，桜井・大谷（1997）ではバリマックス 回転により探索的因子分析が行われたが, Stoeber \& Otto (2006) によると多くの研究で完 全主義的努力と完全主義的懸念の間には中程度以 上の正の相関が認められているため, 本研究では 完全主義的努力と完全主義的懸念間の因子間相関 を仮定した分析を行うこととした。CSWSについ ては最尤法・プロマックス回転による探索的因子 分析を行い，達成動機測定尺度については先行研 究（堀野・森，1991）と同様にバリマックス回転 による探索的因子分析を行って因子を確定した。 因子負荷量が.35以下の項目，他の因子と.35以上 でダブルローディングした項目があった場合は削 除した。本研究で新たに作成した 1 因子から構成 される失敗の反すう尺度㧍よび失敗回避動機尺度 については，それぞれ主成分分析を行い，1つの 合成変数として集約できるかを確認した ${ }^{2)}$ 。内的 一貫性の確認指標として，因子を構成する項目の 因子負荷がすべて等しいと仮定する $\alpha$ 係数の制約 を取り除いた $\omega$ 係数（室橋, 2003）のほうが, 信頼性の指標として良いと近年では指摘されてい
る（清水, 2007）。そのため本研究では, 尺度の 内的一貫性の検討には $\omega$ 係数を用いたが, 従来 の研究との比較のために $\alpha$ 係数も合わせて算出し ている。

各变数の関連を検討するため相関係数を求め た。不健全完全主義者の学業課題への動機づけの 媒介要因を明らかにするため, 完全主義を説明変 数, 随伴性自己価值と失敗の反すうを媒介変数, 動機づけを目的変数とする媒介分析を行った。

相関分析および偏相関分析，媒介分析には SPSS ver.22を用いた。確認的因子分析にはStata/ SE ver. 13.1を用い，探索的因子分析および主成 分分析, 信頼性係数の推定值の算出にはHAD (清 水・村山・大坊，2006）のver.12.031を用いた。

因子構造の確認 新完全主義尺度は原尺度のう ち該当する 2 因子から 5 項目ずつを抜粋して使用 したため, 確認的因子分析を行うことで因子構造 の確認を行った。高目標設置の指標である完全主 義的努力因子と失敗過敏の指標である完全主義的 懸念因子の 2 因子モデルの適合度は， $\chi^{2}$ 值は有意 であったものの $\left(\chi_{(34)}^{2}=76.866, p<.01\right), \mathrm{CFI}=.933$, $\mathrm{RMSEA}=.083(90 \% \mathrm{CI}[0.058,0.107]), \quad \mathrm{SRMR}=.072$ であった。これらは十分な值とは言いがたいが, ある程度の適合度が示されたため，これまでの完 全主義研究の知見と比較することを考慮し，本研 究では2因子モデルを採用した。信頼性係数の推

2）主成分分析の結果, 失敗の反すう尺度は 4 項目から なる 1 因子構造での解釈が可能と判断した（累積寄 与率 $70.75 \%) 。$ 信頼性係数の推定值は $\omega=.91, \alpha=.86$ と高い内的一貫性を示した。同様に, 失敗回避動機 尺度は 4 項目からなる 1 因子構造での解釈が可能と 判断した（累積寄与率 $48.94 \%$ )。信頼性係数の推定 值は $\omega=.79, \alpha=.64$ であった。 $\omega$ 係数が高いことよ り, 失敗回避動機尺度も十分な内的一貫性を示した と推察される。Table 1の通り失敗回避動機は, 高い 成果を得たい点で共通する競争的達成動機とは中程 度の正の相関 $(r=.42, p<.01)$ を示したが，成果と は関係なく独自の達成基準を目指す自己充実的達成 動機とは無相関 $(r=-.06, n . s$.$) であったことより，$ 基準関連妥当性は認められたと言える。 
Table 1 各変数の相関および記述統計量

\begin{tabular}{|c|c|c|c|c|c|c|c|c|}
\hline & \multirow{2}{*}{$\begin{array}{l}\text { 完全主義的 } \\
\text { 努力 }\end{array}$} & \multirow{2}{*}{$\begin{array}{c}\text { 完全主義的 } \\
\text { 懸念 }\end{array}$} & \multicolumn{2}{|c|}{ 随伴性自己価值 } & \multirow{2}{*}{$\begin{array}{l}\text { 失敗の } \\
\text { 反すう }\end{array}$} & \multicolumn{2}{|c|}{ 動機づけ } & \multirow{2}{*}{ Mean $(S D)$} \\
\hline & & & 活動価值 & 成功価値 & & 自己充実的達成 & 競争的達成 & \\
\hline 完全主義的努力 & - & & & & & & & $2.81(0.80)$ \\
\hline 完全主義的懸念 & $.32^{* *}$ & - & & & & & & $1.99(0.87)$ \\
\hline 活動価値 & $.62^{* *}$ & $.43^{* *}$ & - & & & & & $2.61(0.91)$ \\
\hline 成功価值 & $.21^{* *}$ & $.54^{* *}$ & $.38^{* *}$ & - & & & & $2.57(1.02)$ \\
\hline 失敗の反すう & $.21^{* *}$ & $.50 * *$ & $.32 * *$ & $.60^{* *}$ & - & & & $3.02(0.94)$ \\
\hline 自己充実的達成動機 & $.35^{* *}$ & $-.14^{\dagger}$ & $.17^{*}$ & $-.14^{\dagger}$ & -.09 & - & & $3.40(0.63)$ \\
\hline 競争的達成動機 & $.48^{* *}$ & $.34^{* *}$ & $.44^{* *}$ & $.26^{* *}$ & $.30^{* *}$ & .04 & - & $3.45(0.76)$ \\
\hline 失敗回避動機 & $.20^{* *}$ & $.61^{* *}$ & $.27^{* *}$ & $.32^{* *}$ & $.40^{* *}$ & -.06 & $.42^{* *}$ & $2.65(0.63)$ \\
\hline
\end{tabular}

注. Mean および $S D$ に各変数の記述統計量を示す。

** $p<.01,{ }^{*} p<.05,{ }^{\dagger} p<.10$

定值は完全主義的懸念で $\omega=.83, \alpha=.80$, 完全主 義的努力で $\omega=.80, \alpha=.78$ と十分な内的一貫性が 確認された。

CSWSの探索的因子分析では, 因子負荷量 が.335と.192だった「私の人生の中において本 当に価值があることは, 働いたり, 勉強したりす ることである」という項目および, 因子負荷量が 一.178とー.068だった「自分の価值が, 自分が成 し遂げたことによって決まるとは思わない」とい う項目を削除した。最終的に, 活動価值因子 3 項 目および成功価值因子 2 項目から成る 2 因子構造 であることが確認された（累積寄与率 $64.11 \%) 。$ 信頼性係数の推定值は活動価值で $\omega=.64$, $\alpha=.62$, 成功価值で $\omega=.63, \alpha=.61$ であり, 内的 一貫性はあまり高くはなかった。CSWSの妥当性 については, 先行研究 (DiBartolo et al., 2004) では「課題への取り組みや成果に基づいて自己評 価を行うため, 高い目標を掲げる」という観点か ら, FMPSの高目標設置との相関を確認している。 高目標設置と活動価値との相関は.47, 成功価值 との相関は.37であった。Table 1 の通り, DiBartolo et al. (2004) と比べ, 本研究で用いた完全主義的 努力と活動価值との相関は.62 と高く, 成功価值 との相関は.21 と同じ程度であった。仕事熱心と いう特徵が見られる日本的夕イプ A (鷲見・内村,
1994）のように，日本では課題に取り組むことは 勤勉であると良いイメージを持たれていることを 踏まえると, 活動価值と完全主義的努力の相関が 先行研究（DiBartolo et al., 2004）よりも高いの は妥当であると言える。以上より, 翻訳した CSWSの基準関連妥当性は確認された。

達成動機測定尺度は, 探索的因子分析の結果, 先行研究 (堀野. 森, 1991) と同様の各因子 4 項 目からなる 2 因子構造であることが確認された (累積寄与率 $58.26 \%$ )。信頼性係数の推定值は競 争的達成動機で $\omega=.82, \alpha=.80$, 自己充実的達成 動機で $\omega=.64, \alpha=.60$ であった。

各变数の関連 相関分析の結果 (Table 1), 完 全主義的努力や完全主義的懸念はすべての変数と 弱から強程度の正の相関を示した $(r s=.20-.62$, $p s<.01)$ 。ただし，完全主義的努力と完全主義的 懸念の間に弱い正の相関がある $(r=.32, p<.01)$ ため, 互いの影響が交絡した結果, 他の変数と弱 い相関が認められた可能性がある。そこで完全主 義的努力と完全主義的懸念において, もう一方の因 子の影響を統制した偏相関分析を行った（Table 2)。 完全主義的懸念を統制すると, 完全主義的努力は 活動価值や自己充実的達成動機, 競争的達成動 機と中程度の正の相関を示すことがわかった $\left(r_{p} \mathrm{~s}\right.$ $=.42-.56, p \mathrm{~s}<.01)$ 。また, 活動価值は自己充実 
Table 2 各変数の偏相関分析の結果

\begin{tabular}{|c|c|c|c|c|c|c|c|}
\hline & \multirow{2}{*}{$\begin{array}{l}\text { 完全主義的努力／ } \\
\text { 完全主義的懸念 }\end{array}$} & \multicolumn{2}{|c|}{ 随伴性自己価值 } & \multirow{2}{*}{$\begin{array}{l}\text { 失敗の } \\
\text { 反すう }\end{array}$} & \multicolumn{3}{|c|}{ 動機づけ } \\
\hline & & 活動価値 & 成功価值 & & $\begin{array}{l}\text { 自己充実的 } \\
\text { 達成動機 }\end{array}$ & $\begin{array}{l}\text { 競争的 } \\
\text { 達成動機 }\end{array}$ & $\begin{array}{c}\text { 失敗回避 } \\
\text { 動機 }\end{array}$ \\
\hline 完全主義的努力 /完全主義的懸念 & & $.56^{* *}$ & .04 & .06 & $.42 * *$ & $.42 * *$ & .01 \\
\hline 活動価值 & $.31^{* *}$ & & $.19^{*}$ & $.13^{\dagger}$ & $.26^{* *}$ & $.34^{* *}$ & .01 \\
\hline 成功価値 & $.51^{* *}$ & $.32 * *$ & & $.45^{* *}$ & -.08 & .10 & -.01 \\
\hline 失敗の反すう & $.47^{* *}$ & $.25^{* *}$ & $.58^{* *}$ & & -.03 & $.16^{*}$ & $.13^{\dagger}$ \\
\hline 自己充実的達成動機 & $-.28^{* *}$ & -.06 & $-.23^{* *}$ & $-.18^{*}$ & & .10 & .03 \\
\hline 競争的達成動機 & $.22 * *$ & $.20 * *$ & $.19^{*}$ & $.23^{* *}$ & $-.15^{*}$ & & $.29^{* *}$ \\
\hline 失敗回避動機 & $.59^{* *}$ & $.19^{*}$ & $.29 * *$ & $.37^{* *}$ & $-.14^{\dagger}$ & $.37^{* *}$ & \\
\hline
\end{tabular}

注. 対角線の右上の数值は, 完全主義的懸念を統制したうえでの各変数の偏相関係数を示している。最上段の数伹は完全主義的努 力と各変数の偏相関係数を示す。対角線の左下の数值は, 完全主義的努力を統制したうえでの各変数の偏相関係数を示してい る。左端行の数值は完全主義的懸念と各変数の偏相関係数を示す。

** $p<.01,{ }^{*} p<.05,{ }^{\dagger} p<.10$

的達成動機や競争的達成動機と弱い正の相関が認 められた $\left(r_{p} s=.26-.34, p s<.01\right)$ 。

一方完全主義的努力を統制すると，完全主義的 懸念は随伴性自己価值や失敗の反すう, 競争的達 成動機, 失敗回避動機と弱から中程度の正の相関 $\left(r_{p} s=.22-.59, p s<.01\right)$ が認められ，自己充実的 達成動機とは弱い負の相関 $\left(r_{p}=-.28, p<.01\right)$ が認められた。活動価值や成功価值，失敗の反す うは競争的達成動機や失敗回避動機と弱い正の相 関を示した $\left(r_{p} s=.19-.37, p s<.05\right)$ 。また，成功 価值と失敗の反すうは自己充実的達成動機と弱い 負の相関が認められた $\left(r_{p} \mathrm{~s}=-.18--.23, p s<.05\right) 。$

\section{完全主義が学業課題への動機づけに及ぼす影響} の媒介過程の検討 Preacher \& Hayes（2008）に よるマクロを用いて, 完全主義を説明変数, 随伴 性自己価值および失敗の反すうを媒介変数, 動機 づけを目的変数とするブートストラップ法による 媒介分析を行った（Table 3)。媒介効果を検討す る方法として，精度が高い Bias Corrected and Accelerated 法（BCa法; Efron, 1987）を用いた。 なお， $\mathrm{BCa}$ 法は間接効果の信頼区間のみが算出さ れ, 総合効果や直接効果の信頼区間は算出されな い。媒介効果を仮定する変数は偏相関分析の結果
に基づいて選択した。完全主義的努力を説明変数 とする媒介分析では活動価值のみを投入し，完全 主義的懸念を説明変数とする媒介分析では活動価 值および成功価值，失敗の反すうを媒介変数に投 入した。なお，完全主義の下位因子間の影響の交 絡を統制するため，完全主義的努力を説明変数と する分析では完全主義的懸念を，完全主義的懸念 を説明変数とする分析では完全主義的努力を共変 量に投入した。リサンプリングは1000回行い， 信頼区間を構成した。完全主義と動機づけとの偏 相関は随伴性自己価值や失敗の反すうと動機づけ との偏相関よりも高いことから, 統計的に媒介効 果が認められにくい恐れがあるため，95\%信頼区 間だけではなく $90 \%$ 信頼区間も算出した。総合 効果 $(c)$ は完全主義から動機づけへの影響の全 体像を示す。直接効果 $\left(c^{\prime}\right)$ は, 媒介变数に媒介 されずに完全主義が動機づけへ直接及ぼす影響の 程度を示す。間接効果 $\left(c-c^{\prime}\right)$ は完全主義から随 伴性自己価值や失敗の反すうへの影響と, 随伴性 自己価值や失敗の反すうから動機づけへの影響の 積を示す。Table 3 の上のカッコ内の数值は間接 効果の 95\% 信頼区間を, 下のカッコ内の数值は 間接効果の $90 \%$ 信頼区間を示している。区間内 
Table 3 媒介分析の結果

\begin{tabular}{|c|c|c|c|c|}
\hline & & $\begin{array}{l}\text { 自己充実的 } \\
\text { 達成動機 }\end{array}$ & $\begin{array}{c}\text { 競争的 } \\
\text { 達成動機 }\end{array}$ & 失敗回避動機 \\
\hline \multirow[t]{6}{*}{ 完全主義的努力 } & 総合効果 $(c)$ & $.438^{* *}$ & $.419^{* *}$ & \\
\hline & 直接効果 $\left(c^{\prime}\right)$ & $.420^{* *}$ & $.332 * *$ & \\
\hline & 間接効果 $\left(c-c^{\prime}\right)$ & & & \\
\hline & 活動価値 & .018 & .087 & \\
\hline & & $(-.083, .125)$ & $(-.001, .202)$ & \\
\hline & & $(-.072, .100)$ & $(.009, .176)$ & \\
\hline \multirow[t]{12}{*}{ 完全主義的懸念 } & 総合効果 $(c)$ & $-.278^{* *}$ & $.199^{* *}$ & $.610^{* *}$ \\
\hline & 直接効果 $\left(c^{\prime}\right)$ & $-.216^{*}$ & .095 & $.579^{* *}$ \\
\hline & 間接効果 $\left(c-c^{\prime}\right)$ & & & \\
\hline & 活動価値 & & .038 & .001 \\
\hline & & & $(-.011, .109)$ & $(-.052, .055)$ \\
\hline & & & $(-.002, .099)$ & $(-.040, .047)$ \\
\hline & 成功価値 & -.054 & .007 & -.046 \\
\hline & & $(-.147, .067)$ & $(-.080, .110)$ & $(-.140, .040)$ \\
\hline & & $(-.143, .051)$ & $(-.065, .080)$ & $(-.126, .037)$ \\
\hline & 失敗の反すう & -.008 & .060 & .076 \\
\hline & & $(-.107, .086)$ & $(-.025, .156)$ & $(.002, .165)$ \\
\hline & & $(-.093, .071)$ & $(-.008, .139)$ & $(.011, .142)$ \\
\hline
\end{tabular}

注. Preacher \& Hayes (2008) のマクロを用いて, Bootstrap（1000回）による信頼区間推定を行った。間接効果の上のカッコ内の 数值は $95 \%$ 信頼区間を示し, 下のカッコ内の数值は $90 \%$ 信頼区間を示す。完全主義の下位尺度間の影響の交絡を統制するため, 完全主義的努力が動機づけへ及ぼす影響を検討する媒介分析では, 完全主義的懸念を共変量に投入した。同様に, 完全主義的 懸念が動機づけへ及ほすす影響を検討する媒介分析では，完全主義的努力を共変量に投入した。なお，随伴性自己価値および失 敗の反すうのうち, 偏相関分析で完全主義书よび動機づけの両変数と偏相関を示さなかった変数については, 媒介効果を仮定 する変数に投入しなかったため，空欄となっている。

** $p<.01,{ }^{*} p<.05,{ }^{\dagger} p<.10$

に0が含まれていなければ，統計的に有意な媒介 効果が認められたことを意味する。

完全主義的努力は, 自己充実的達成動機や競争 的達成動機に直接的に正の影響を及ぼした（ $c^{\prime} \mathrm{s}$ $=.332-.420, p s<.01)$ 。また, 完全主義的努力は 活動価値に媒介されて競争的達成動機に正の影響 を及ぼす傾向があることがわかった $\left(c-c^{\prime}=.087\right.$, $90 \%$ CI $[.009, .176])$ 。完全主義的懸念は，自己充 実的達成動機へ直接的に負の影響 $\left(c^{\prime}=-.216\right.$, $p<.05 ）$ を, 失敗回避動機には直接的に正の影響 $\left(c^{\prime}=.579, p<.01\right)$ を及ぼした。また，完全主義 的懸念は失敗の反すうに媒介されて失敗回避動機 に正の影響を及ぼした $\left(c-c^{\prime}=.076,95 \%\right.$ CI [.002， .165])。しかし，完全主義的懸念が随伴性自己価 值に媒介されて動機づけへ及ぼす影響は認められ
なかった。

\section{考察}

本研究の目的は不健全完全主義者の学業課題へ の高い動機づけの媒介要因を明らかにすることで あった。

媒介分析の結果，完全主義的努力は自己充実的 達成動機と競争的達成動機に直接的に正の影響を 及ぼし，完全主義的懸念は自己充実的達成動機に 直接的に負の影響を及ぼしていた。また，完全主 義的努力は活動価值に媒介されて競争的達成動機 に正の影響を及ぼす傾向も示された。よって，仮 説 1 は部分的に支持された。

完全主義的懸念は失敗回避動機に直接的に正の 影響を及ぼすことがわかった。さらに完全主義的 
懸念は, 失敗の反すうに媒介されて失敗回避動機 に正の影響を及ぼしたことより，仮説 2 は支持さ れた。

本研究において, 完全主義的努力は活動価値に 媒介されて競争的達成動機に正の影響を及ぼす傾 向にあることが認められたことは, DiBartolo et al. (2004) の知見と一致していた。完全主義的努 力が高いと課題に取り組むことに価值を置くた め, 人より優れた成果を求めて競争心を高める傾 向にあると推察される。また，完全主義的努力は 直接効果として自己充実的達成動機や競争的達成 動機と正の関連があることや，さらに完全主義的 努力は随伴性自己価值と比べ，自己充実的達成動 機や競争的達成動機と同程度か若干強い正の相関 があることが示された。これらの結果は，完全主 義的努力傾向が高い者は自己価值を維持するため に動機づけが高い（DiBartolo et al., 2004）とい うより，純粋に高い目標を掲げるという知見 （Kobori et al., 2009）を支持する結果だと言える。 完全主義的努力から達成動機への直接効果と媒介 効果傾向が共に認められたことから，完全主義的 努力傾向が高い者が高い達成基準を自己に課すの は，高い達成基準を設定する行動が定着している だけではなく，課題や高い目標に取り組むことで 自己価值を高揚させるためでもあると推察され る。

また，完全主義的努力は自己充実的達成動機に 正の直接効果を示したものの, 活動価值に媒介さ れた媒介効果は認められなかった。相関分析では 活動価值は自己充実的達成動機と正の関連が認め られたが，完全主義的努力を統制すると，その関 連は認められなくなった。DiBartolo et al. (2004) も指摘するように随伴性自己価值は取り組みや成 果によって自己評価を行う点で不適応的であるた め，成果に関係なく自分なりの目標を目指す自己 充実的達成動機とは結びつかなかったと考えられ る。

一方，完全主義的懸念は自己充実的達成動機と
直接的に負の関連を示した。完全主義的懸念傾向 が高い者は失敗を犯すことを過度に恐れる（Frost et al., 1990）ため, 完全主義的懸念傾向が高いほ ど，自己充実的達成動機が低くなることは妥当な 結果だ考えられる。また, 完全主義的懸念から 競争的達成動機への総合効果は認められたが, 直 接効果と間接効果は認められなかった。相関分析 では完全主義的懸念や随伴性自己価值は競争的達 成動機と弱から中程度の正の相関を示したもの の，完全主義的努力を統制するとその関連は弱く なった。以上より, 完全主義的懸念が競争的達成 動機の高さと結びつくのは, 完全主義的努力の高 さが交絡した結果であると言える。

完全主義的懸念は失敗の反すうに媒介されて失 敗回避動機に正の影響を及ぼしていたことは, Frost \& Henderson (1991) の知見と一致してい た。完全主義的懸念傾向が高いと失敗を何度も思 い起こすことで，失敗への注意を喚起して失敗回 避動機が高くなると推察される。また完全主義的 懸念は失敗回避動機と直接的に正の関連があるこ とや，完全主義的懸念は失敗の反すうより失敗回 避動機と強い正の関連があることが示された。こ れらの結果より，完全主義的懸念傾向の高い者が 高い失敗回避動機を抱くのは，失敗を回避しょう とする行動が定着しているだけではなく，犯した 失敗を意識し続けることで少しでも失敗を回避し ようとしているからだと考えられる。

本研究の結果から, 不健全完全主義者の学業課 題への高い動機づけの媒介過程として, (1)完全主 義的努力傾向が高いと課題への取り組みに自己価 值を置くため競争的達成動機が高い傾向にあるこ と, (2)完全主義的懸念傾向が高いと犯した失敗を 繰り返し考えてしまうため失敗回避動機が高いこ とがわかった。これらの結果から, 不健全完全主 義者は学業課題に取り組むこと自体が自己価值を 高めること，また課題を十分に成し遂げることが できなかったとしても課題へ取り組んだことによ り自己を正当化していることが推測される。その 
ため不健全完全主義者の失敗回避動機の高さは, 失敗を犯さないように課題を回避するのではな く, 失敗をなくすために課題に過剩に取り組むこ とにつながる（石田，2005）と考えられる。

不健全完全主義者の高い動機づけはうつ病など の不適応状態に結びつくだけではなく，その治療 効果も弱めてしまう恐れがある（Blatt, Zuroff, Bondi, Sanislow, \& Pilkonis, 1998)。不健全完全 主義者の達成動機は活動価值に, 失敗回避動機は 失敗の反すうに媒介されているという本研究の知 見に基づくならば，うつ病の短期治療を受けても 改善しにくかった不健全完全主義者の高い動機づ けへ介入する方法が案出できる。例えば認知行動 療法を用い，失敗を犯すことを気にしないように 認知を変容させることで不健全完全主義者の失敗 への過敏な反応を減らし, 課題に取り組んだ姿勢 を肯定的に評価することで不健全完全主義者で あっても課題に取り組むことで適応性を高めるこ とができると考えられる。

本研究の限界点として, 達成動機の尺度の信頼 性があまり高くないためデー夕の安定性に問題が 挙げられる。想像された日常の学業課題が多様で あるために，動機づけの個人差が大きくなったと 考えられることから，今後は課題場面を統制した 検討が求められる。また, CSWSの信頼性もあま り高くはなかった。下位因子の歪度 $(S k)$ と尖度 $(K u)$ を求めると, 活動価值では $S k=-.040$,

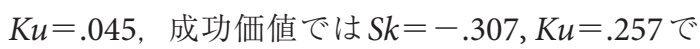
あり, 多くの回答が「やや当てはまらない」や「や や当てはまる」に偏る傾向が認められた。 DiBartolo et al. (2004) によると，随伴性自己価 值が高いと病理的問題につながる恐れがあること から, 内的一貫性はあまり高くはないとされる （活動価值 $\alpha=.66$, 成功価值 $\alpha=.71$ ）。このこと より, 項目自体が臨床的意味合いを持ち, そのこ とが得点に影響し，分布が歪んだと考えられる。 今後はCSWSの質問項目数を増やし，内容を吟味 することで内的一貫性の高い尺度を開発する必要
がある。その上でより臨床群に近い者を対象とし て, 同様の関連が認められるか確認することが求 められる。さらに, 講義終了後に調査を実施した ため欠損や誤った回答が多く, 全回答者のうち約 $25 \%$ の回答者をデータから除かざるを得なくなっ た。今後は回答者の疲労感の少ない授業開始時に 調査を実施することが必須である。

\section{引用文献}

Bieling, P. J., Israeli, A., Smith, J., \& Antony, M. M. (2003). Making the grade: The behavioural consequences of perfectionism in the classroom. Personality and Individual Differences, 35, 163-178.

Blatt, S. J., Zuroff, D. C., Bondi, C. M., Sanislow, C. A. III, \& Pilkonis, P. A. (1998). When and how perfectionism impedes the brief treatment of depression: Further analyses of the National Institute of Mental Health Treatment of Depression Collaborative Research Program. Journal of Counseling and Clinical Psychology, 66, 423-428.

DiBartolo, P. M., Frost, R. O., Chang, P., LaSota, M., \& Grills, A. E. (2004). Shedding light on the relationship between personal standards and psychopathology: The case for contingent self-worth. Journal of Rational-Emotive and Cognitive Behavior Therapy, 22, 241-254.

Efron, B. (1987). Better bootstrap confidence intervals. Journal of the American Statistical Association, 82, 171-185.

Flett, G. L., Hewitt, P. L., Oliver, J. M., \& Macdonald, S. (2002). Perfectionism in children and their parents: A developmental analysis. In G. L. Flett \& P. L. Hewitt (Eds.), Perfectionism: Theory, research, and treatment. Washington, DC: American Psychological Association. pp. 89-132.

Frost, R. O., \& Henderson, K. J. (1991). Perfectionism and reactions to athletic competition. Journal of Sport and Exercise Psychology, 13, 323-335.

Frost, R. O., Marten, P., Lahart, C., \& Rosenblate, R. (1990). The dimensions of perfectionism. Cognitive Therapy and Research, 14, 449-468.

堀野緑・森 和代 (1991). 抑うつとソーシャルサ ポートの関連に介在する達成動機の要因 教育心理 学研究, 39, 308-315. 
石田裕昭 (2005). 大学生の完全主義傾向と課題解決 方略の非効率性——なぜ彼らの努力は報われないの か——社会心理学研究, 20, 208-215.

伊藤 拓・上里一郎 (2001). ネガティブな反すう尺度 の作成およびうつ状態との関連性の検討 カウンセ リング研究, 34, 31-42.

Kobori, O., Hayakawa, M., \& Tanno, Y. (2009). Do perfectionists raise their standards after success? An experimental examination of the revaluation of standard setting in perfectionism. Journal of Behavior Therapy and Experimental Psychiatry, 40, 515-521.

室橋弘人 (2003). 低い $\alpha$ 係数 豊田秀樹（編）共分散 構造分析 [疑問編］一一構造方程式モデリング— 朝倉書店 pp. 79-81.

西田悠作 (2009). 防衛的悲観主義のストレス対処過程 についての検討一一対処の柔軟性について——広 島大学総合科学部総合科学科卒業論文 (未公刊).

Preacher, K. J., \& Hayes, A. F. (2008). Asymptotic and resampling strategies for assessing and comparing indirect effects in multiple mediator models. Behavior Research Methods, 40, 879-891.

坂本真士 (1997). 自己注目と抑うつの社会心理学 東 京大学出版会
桜井茂男 ·大谷佳子（1997）。“自己に求める完全主義” と抑うつ傾向および絶望感との関係 心理学研究,

68, 179-186.

Shafran, R., Cooper, Z., \& Fairburn, C. G. (2002). Clinical perfectionism: A cognitive-behavioural analysis. Behaviour Research and Therapy, 40, 773-791.

清水裕士 ・村山 綾・大坊郁夫 (2006). 集団コミュ ニケーションにおける相互依存性の分析（1）—— ミュニケーションデータへの階層的データ分析の適 用——電子情報通信学会技術研究報告, 106, 1-6.

清水和秋 (2007). $\alpha$ はやめて $\omega$ にしょう一一因子分析 で構成した尺度の共通性と信頼性——日本心理学 会第 71 回大会発表論文集, 416 .

Skinner, B. F. (1938). The behavior of organisms: An experimental analysis. New York: Appleton Century.

Stoeber, J., \& Otto, K. (2006). Positive conceptions of perfectionism: Approaches, evidence, challenges. Personality and Social Psychology Review, 10, 295-319. 熟見克典・内村義弘 (1994). 日本的夕イプ A 行動パター ンとストレス 名古屋工業大学紀要, 46, 297-312.

-2014.8.26受稿, 2015.9.1受理一 


\title{
The Effects of Contingent Self-Worth and Rumination about Failure on Maladaptive Perfectionists' Motivation in Academic Situations
}

\author{
Ayano (Masui) Ebisu and Makoto Iwanaga \\ Graduate School of Integrated Arts and Sciences, Hiroshima University \\ The Japanese Journal of Personality 2016, Vol. 24 No. 3, 190-201
}

\begin{abstract}
Maladaptive perfectionists tend to set high standards for academic tasks, even if they cannot achieve their standards. How do they sustain high academic motivation? The present study investigated the mediators affecting high academic motivation observed in maladaptive perfectionists. We examined the relationships between perfectionism, contingent self-worth, rumination about failure, and motivation for daily academic tasks in undergraduates $(N=185)$. Multiple mediational analyses indicated that perfectionistic strivings positively and directly affected achievement motivation. Activity-based self-worth marginally mediated between perfectionistic strivings and achievement motivation through competition. Moreover, perfectionistic concerns negatively and directly affected achievement motivation through self-fulfillment, and positively and directly affected failure-avoidant motivation. Rumination about failure significantly mediated between perfectionistic concerns and failure-avoidant motivation. These results suggest that the high academic motivation observed in maladaptive perfectionists is mediated by activity-based self-worth and rumination about failure.
\end{abstract}

Key words: perfectionism, contingent self-worth, rumination about failure, achievement motivation, failure-avoidant motivation 